\title{
The Melting Properties of Tuyere Slags with and without Flux Injection into the Blast Furnace
}

\author{
Lena Sundqvist ÖKVIST
}

Division of Ironmaking, SSAB Tunnplåt, SE-971 88 Luleå, Sweden. Also PhD student, Luleå University of Technology, SE-971 87

Luleå, Sweden. E-mail: lena.sundqvist@ssab.com

(Received on June 29, 2001; accepted in final form on September 5, 2001)

\begin{abstract}
A laboratory study concerning the melting properties of tuyere slags has been conducted. The meltingpoint measurements of various specimens, consisting of coke ash, coal ash and fluxes (BOF slag, burnt lime and burnt dolomite), corresponding to the tuyere slags formed in front of the tuyeres with or without flux injection, have been performed in a high-temperature microscope. Theoretical estimations of melting points have been made based on the chemical composition of the tuyere slag specimens.

The results have shown that injection of fluxes has quite a positive effect on the melting properties of the tuyere slag. The melting point of the tuyere slag decreases and the temperature interval between softening and complete melting of the tuyere slag becomes narrower. Compared to the injection of burnt lime and burnt dolomite, the injection of BOF slag will result in still better tuyere slag properties in terms of lower flow point and narrower temperature interval between softening and melting. The differences in melting behaviour in the tuyere slag specimens indicate that injection of BOF slag will also give the tuyere slag a lower viscosity compared to injection of burnt lime or burnt dolomite at the same levels of slag basicity B2.
\end{abstract}

KEY WORDS: flux injection; tuyere slag; melting-point measurements.

\section{Introduction}

In the blast furnace, reduction of iron ores and calcination of limestone proceed when the burden materials descend. Different types of slag will be formed at different locations:

a) Primary slag-formed by the gangue in the pellets;

b) Bosh slag-consisting of the primary slag, all the additives and fluxes dissolved in it and some ash from coke consumed for direct reduction and carburisation;

c) Tuyere slag-formed by the ash content of coke and coal burnt in front of the tuyeres and, if injection of fluxes are used, the injected flux;

d) Final slag-formed by a mixture of bosh slag and tuyere slag changed in composition by reduction of some $\mathrm{SiO}_{2}$ to $\mathrm{Si}$.

At the level of the cohesive zone, softening and melting of iron burden occur, accompanied by dissolution of fluxes. Normally, the bosh slag has a higher basicity compared to the primary slag and the final slag. If the pellet contains a very low amount of gangue and the ash content of the coke is quite high, the top-charged fluxes are mainly used to neutralise the coke ash at the tuyere level of the furnace. A slag of excessive basicity is formed in the bosh part, which was considered as one of the main causes of slag formation problems during testing of a new self-fluxed pellet at SSAB in 1995. A theoretical estimation of the changes in the basicity of the slag formed at different levels of the blast furnace showed that the basicity $\mathrm{B} 2=1$ in the primary slag of the pellet increased to approximately 1.6 in the bosh slag.
The basicity of the tuyere slag was 0.05 and the final slag had a desired slag basicity of 1.2. ${ }^{1)}$

To decrease the variations in slag basicity and the slag amount in the cohesive zone, $\mathrm{Ma}^{1)}$ has proposed injection of fluxes through the tuyeres, instead of charging them from the top, to improve slag formation in the blast furnace. The basicity B2 of primary slag of the pellet, bosh slag, tuyere slag and final slag will then be 1.0, 1.1, 0.9 and 1.2, respectively. In this case, a smooth slag formation process, increased productivity and decreased fuel rate can be achieved. In Fig. 1 the basicity of slag formed at different locations in the blast furnace is compared for normal blast furnace operation and operation with injection of fluxes through the tuyeres when using self-fluxed pellets. The formation of high basicity slag when basic flux is added to self-fluxed pellets and the effect of this on melting behaviour of burden have been verified in laboratory tests. The positive effect of basic fluxes on melting properties of acid pellet is also evident when a certain amount of basic flux is added. $^{2,3)}$

Injection of iron ore and different fluxes has been tested in some blast furnaces to adjust the sulphur and silicon contents of hot metal. ${ }^{4-8)}$ In a study concerning the effect of tuyere injection of dolomite on the Si content of hot metal it was found that the increased $\mathrm{MgO}$ content of the tuyere slag decreased the $\mathrm{SiO}_{2}$ activity in the slag and the generation of $\mathrm{SiO}$ gas decreased. The effect of $\mathrm{MgO}$ on the generation of $\mathrm{SiO}$ gas decreased with increased basicity $\mathrm{B} 2$ of the slag. ${ }^{4)}$ The injection of iron-ore powder only, did not have any effect on the Si content of the hot metal, while a 
powder mixture of flux and iron ore did decrease the $\mathrm{Si}$ content. The positive effect of flux powder was explained by $\mathrm{SiO}$ absorption by the flux powder. ${ }^{5}$ In another study on injection of iron ore fines it was found that the Si content was decreased as a result of increased partial pressure of oxygen in the end of the raceway. If sinter fines containing $\mathrm{CaO}$ was used the effect was higher. ${ }^{6}$ In another study of the injection, a mixture of iron ore and coal or a water slurry containing iron ore resulted in decreased $\mathrm{Si}$ content of hot metal. The oxidation degree of the slag in the hearth and bosh was considered to be a key factor controlling $\mathrm{Si}$ content of hot metal. ${ }^{7)}$ The different results achieved in the iron ore injection studies might be explained by the particle size of the injected iron ore. ${ }^{8)}$ The original oxidation degree of slags in the bosh and the hearth will affect the result. ${ }^{5)}$ When a very fine grain size of iron ore is used, the reduction in the raceway will be efficient and the amount of residual $\mathrm{FeO}$ limited.

The use of injection of flux via tuyeres in order to obtain smooth slag formation in the blast furnace results in a decrease in the volume of bosh slag and prevents the formation of a bosh slag with excessive basicity. ${ }^{1-3)}$ At normal blast furnace operation, the tuyere slag, formed by the ash content in fuels combusted in front of the tuyeres, is very acidic and has a high viscosity. The injection of fluxes via the tuyeres makes it possible to increase the basicity of the

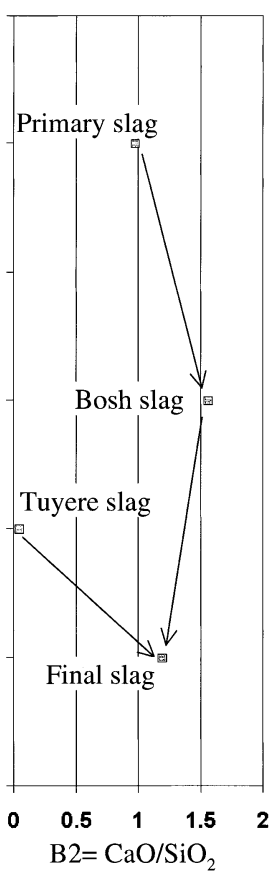

No flux injection

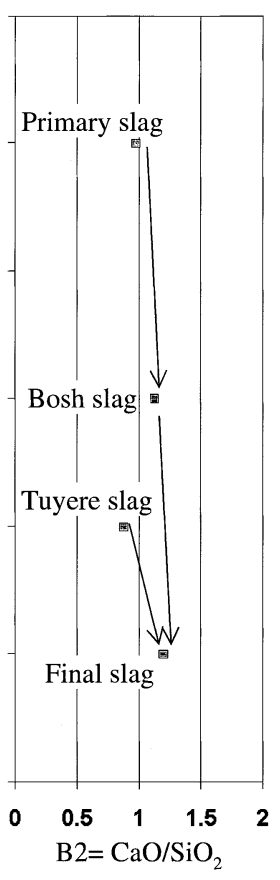

BOF slag injection
Fig. 1. Basicity of slags at different locations in the blast furnace. ${ }^{1)}$ tuyere slag to an appropriate level and improve its melting properties. A lower tuyere slag viscosity might improve the drainage of the slag through the voids in the coke bed. ${ }^{9,10)}$

The aim of this laboratory study is to determine the influence of injected fluxes on the melting properties of the tuyere slag that normally consists of coal and coke ashes. The effect of BOF slag, burnt lime and burnt dolomite on the melting properties of tuyere slag is studied with the aid of melting-point measurements and estimations of melting points from phase diagrams and by model calculations.

The theoretical study by $\mathrm{Ma},{ }^{1)}$ laboratory studies concerning slag formation in the cohesive $z^{2} e^{2,3)}$ and this study of the effect of injection of basic fluxes on the melting properties of tuyere slag have been done to achieve an understanding of the effect of basic fluxes, top-charged or tuyere-injected, on slag formation. Based on the studies in this project, successful trials of injecting BOF slag into the LKAB (A Swedish pellet producer) experimental blast furnace at MEFOS (Metallurgical Research Centre in Luleå) have been done three times. The last two-week test was conducted in late November 2000.

\section{Experimental Technique}

In this study, the tuyere slag is considered to have been formed by a mixture of ash released from coke and coal combusted in front of tuyeres. When injection of flux is assumed, the flux injected is also included in the slag. To make the tested specimens similar to the real tuyere slag formed in front of the tuyeres, the specimens tested are made from a mixture of coke ash, coal ash and fluxes taken from SSAB Tunnplåt in Luleå. Both coke and coal ash are obtained by combustion of coke and coal in a furnace slowly heated up to $800^{\circ} \mathrm{C}$. The coal used is a highly volatile coal containing approximately $38-40 \mathrm{wt} \%$ of volatile matter. The ash contents are 10.6 and $5.8 \mathrm{wt} \%$ and the carbon content 89.5 and $78.2 \mathrm{wt} \%$ of coke and coal, respectively. The chemical compositions of coke ash, coal ash and the three types of fluxes used-BOF slag, burnt lime and burnt dolomite - are to be found in Table $\mathbf{1}$.

The ratio of coke ash, coal ash and fluxes used in specimens varies depending on coke rate, and the amount of coal and fluxes assumed to be injected. The operational conditions of blast furnace No. 2 at SSAB Tunnplåt in Luleå, with a coal injection rate of $120-160 \mathrm{~kg} / \mathrm{thm}$ and at the LKAB pilot blast furnace ${ }^{11)}$ at MEFOS, with a coal injection rate of $\sim 110 \mathrm{~kg} / \mathrm{thm}$, are the basis for determining the correct mixtures of the specimens. The amount of coke consumed in the raceway is calculated according to the different operational conditions with heat and mass balance used for BF No. 3 at SSAB. The estimated result shows that the ratios of coke ash to coal ash for the conditions as-

Table 1. Chemical compositions of coal ash, coke ash and fluxes used for preparation of specimens.

\begin{tabular}{|l|c|c|c|c|c|c|c|c|c|c|c|c|c|}
\hline Sample & $\mathrm{CaO}$ & $\mathrm{MgO}$ & $\mathrm{SiO}_{2}$ & $\mathrm{Al}_{2} \mathrm{O}_{3}$ & $\mathrm{TiO}_{2}$ & $\mathrm{~V}_{2} \mathrm{O}_{5}$ & $\mathrm{MnO}$ & $\mathrm{P}$ & $\mathrm{Na}_{2} \mathrm{O}$ & $\mathrm{K}_{2} \mathrm{O}$ & $\mathrm{Fe}_{2} \mathrm{O}_{3}$ & $\mathrm{FeO}$ & $\mathrm{TFe}$ \\
\hline Coke ash & 0.91 & 0.42 & 50.6 & 29.0 & 1.58 & & & 0.09 & 0.55 & 1.30 & 5.96 & & 4.17 \\
\hline Coal ash & 5.3 & 3.8 & 57.9 & 22.1 & 0.9 & & & 0.1 & 0.3 & 1.7 & 7.1 & & 5.00 \\
\hline BOF-slag & 41.1 & 13.0 & 9.84 & 0.95 & & 4.31 & 3.99 & & & & 8.08 & 16.40 & 18.4 \\
\hline Burnt lime & 92.0 & 1.80 & 2.09 & 1.08 & & & & & & & & & 0.58 \\
\hline $\begin{array}{l}\text { Burnt } \\
\text { Dolomite }\end{array}$ & 52.7 & 38.4 & 1.41 & 0.35 & & & & & & & & & 0.35 \\
\hline
\end{tabular}


Table 2. Amounts of fluxes injected (kg/thm) corresponding to differnt injection levels assumed.

\begin{tabular}{|l|c|c|c|c|c|c|c|c|c|}
\hline \multirow{2}{*}{$\begin{array}{l}\text { Injection } \\
\text { levels of } \\
\text { fluxes }\end{array}$} & \multicolumn{9}{|c|}{ Coal injection rate } \\
\cline { 2 - 11 } & \multicolumn{3}{|c|}{$110 \mathrm{~kg} / \mathrm{thm}$} & \multicolumn{3}{|c|}{$123 \mathrm{~kg} / \mathrm{thm}$} & \multicolumn{3}{|c|}{$150 \mathrm{~kg} / \mathrm{thm}$} \\
\cline { 2 - 11 } & BOF slag & Lime & Dolomite & BOF slag & Lime & Dolomite & BOF slag & Lime & Dolomite \\
\hline None & 0.0 & 0.0 & 0.0 & 0.0 & 0.0 & 0.0 & 0.0 & 0.0 & 0.0 \\
\hline Low & 8.3 & 4.2 & 6.8 & 8.8 & 4.4 & 7.1 & 9.5 & 4.7 & 7.1 \\
\hline Medium & 16.7 & 8.3 & 13.4 & 17.5 & 8.8 & 14.1 & 18.9 & 9.5 & 14.1 \\
\hline High & 33.5 & 12.5 & 20.1 & 35.2 & 13.2 & 21.2 & 37.8 & 14.2 & 21.1 \\
\hline Very High & 50.1 & 16.7 & 26.7 & 52.8 & 17.5 & 28.2 & 56.4 & 18.9 & 28.1 \\
\hline
\end{tabular}

Table 3. Main chemical composition, $\mathrm{wt} \%$, and basicities of the tuyere slag specimens used for melting point measurements.

\begin{tabular}{|c|c|c|c|c|c|c|c|c|c|c|c|c|c|}
\hline & \multirow[b]{2}{*}{ None } & \multicolumn{4}{|c|}{ BOF slag } & \multicolumn{4}{|c|}{ Burnt lime } & \multicolumn{4}{|c|}{ Burnt dolomite } \\
\hline & & Low & Medium & High & $\begin{array}{l}\text { Very } \\
\text { high }\end{array}$ & Low & Medium & High & $\begin{array}{l}\text { Very } \\
\text { high }\end{array}$ & Low & Medium & High & $\begin{array}{l}\text { Very } \\
\text { high }\end{array}$ \\
\hline $\mathrm{CaO}$ & 1.92 & 11.6 & 17.5 & 24.2 & 27.9 & 14.7 & 24.2 & 31.7 & 37.6 & 13.6 & 21.1 & 26.4 & 30.3 \\
\hline $\mathrm{MgO}$ & 1.18 & 4.11 & 5.88 & 7.89 & 9.00 & 1.27 & 1.34 & 1.39 & 1.43 & 9.10 & 14.2 & 17.7 & 20.4 \\
\hline $\mathrm{SiO}_{2}$ & 52.3 & 41.7 & 35.4 & 28.1 & 24.1 & 45.1 & 39.8 & 35.6 & 32.3 & 41.3 & 34.2 & 29.3 & 25.6 \\
\hline $\mathrm{Al}_{2} \mathrm{O}_{3}$ & 27.5 & 20.9 & 16.9 & 12.4 & 9.87 & 23.7 & 20.9 & 18.7 & 17.0 & 21.7 & 18.0 & 15.4 & 13.5 \\
\hline $\mathrm{TiO}_{2}$ & 1.42 & 1.54 & 1.61 & 1.69 & 1.73 & 1.23 & 1.09 & 0.97 & 0.88 & 1.12 & 0.93 & 0.80 & 0.70 \\
\hline $\mathrm{V}_{2} \mathrm{O}_{5}$ & & 1.24 & 1.99 & 2.85 & 3.32 & & & & & 0.01 & 0.02 & 0.02 & 0.03 \\
\hline $\mathrm{MnO}$ & & 0.99 & 1.59 & 2.27 & 2.65 & & & & & & & & \\
\hline $\mathrm{FeO}$ & & 4.07 & 6.5 & 9.3 & 11 & & & & & & & & \\
\hline $\mathrm{Fe}_{2} \mathrm{O}_{3}$ & 6.24 & 6.69 & 7.0 & 7.3 & 7.5 & 5.5 & 4.9 & 4.4 & 4.1 & 5.0 & 4.2 & 3.7 & 3.3 \\
\hline $\mathrm{Fe}_{\text {met }}$ & & 0.93 & 1.9 & 3.7 & 1.9 & & & & & & & & \\
\hline $\mathrm{Fe}_{\mathrm{toL}}$ & 4.36 & 7.84 & 9.95 & 12.3 & 13.7 & 3.82 & 3.42 & 3.11 & 2.86 & 3.50 & 2.95 & 2.56 & 2.27 \\
\hline B2* & 0.04 & 0.28 & 0.49 & 0.86 & 1.17 & 0.33 & 0.61 & 0.89 & 1.16 & 0.33 & 0.62 & 0.90 & 1.18 \\
\hline B4** & 0.05 & 0.32 & 0.57 & 0.99 & 1.35 & 0.28 & 0.50 & 0.72 & 0.93 & 0.49 & 0.91 & 1.33 & 1.75 \\
\hline
\end{tabular}

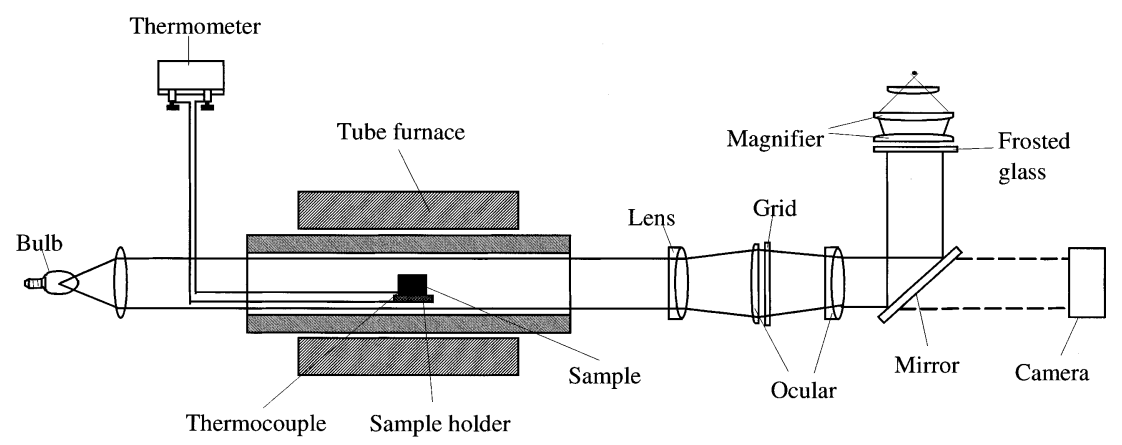

Fig. 2. Schematic drawing of high temperature microscope.

sumed are almost the same. This means that the following results could still be valid, even if some changes in operational condition occur. Five levels of flux injection-none, low, medium, high and very high-are considered for BOF slag, burnt lime and burnt dolomite, respectively. Table 2 shows the different amounts of fluxes to be injected; corresponding to the different injection levels. The coke ash and coal ash obtained are first mixed according to the ratios obtained from the calculation results. To make a specimen representing the tuyere slag at a certain level of flux injection, corresponding amounts of the ash mixture obtained and slag former are mixed and ground in a mortar. The chemical compositions of the specimens stated in Table $\mathbf{3}$, corresponding to different injection levels of fluxes, are obtained from the weight and chemical analyses of materials used. The chemical composition is also analysed and the table is corrected based on this.

The test method used is a standard method used to determine the melting properties of the slag in coal and coke. ${ }^{12)}$ Figure 2 shows a schematic drawing of the high-temperature microscope used. A control unit controls the temperature. The difference between the temperature demanded by the heating programme and the one measured by the thermocouple is used to adjust the electrical current that should be supplied to the furnace. The furnace can be heated up to a maximum temperature of about $1640^{\circ} \mathrm{C}$ and a heating rate of $10^{\circ} \mathrm{C} / \mathrm{min}$ is used at temperatures exceeding $700^{\circ} \mathrm{C}$. A small specimen, about $2 \mathrm{~mm}$ square and $3 \mathrm{~mm}$ high, is used for each test. The sample is placed on an alumina plate on the sample-holder, in which the thermocouple is positioned, and observed with the microscope during heating in a nitrogen atmosphere. To prove that the specimen is not oxidised during the test, one specimen of $\alpha$-iron is melted in the furnace using the same procedure. The oxygen analysis shows that no substantial oxidation occurred. The oxygen content of the iron is $0.014 \%$ before the test and $0.15 \%$ after the test.

Sketches of the samples are constantly drawn to show the changes in the shapes of the samples during heating. The temperatures of softening, active melting and flow point are registered. The definitions of these temperatures are as follows.

- Softening: The contour of the sample gets smooth and no sharp border can be distinguished.

- Active melting: The melting is rapid and the shape of the specimen changes quickly.

- Flow point: The material flows out and the height of the specimen decreases to $1 / 3$ of its original height. 

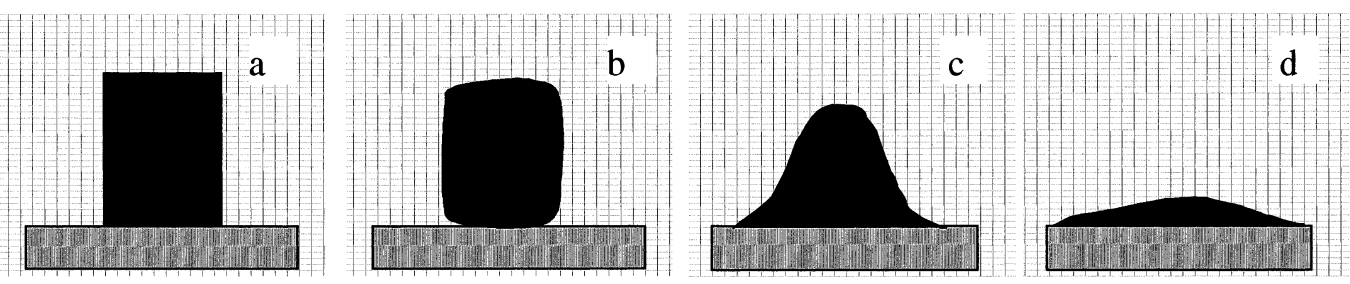

Fig. 3. Contour of sample at start of test (a), softening (b), active melting (c) and flow point (d).

Figure 3 shows an example of the course from softening to flow out of a specimen. In fact, the shapes of the specimens are different for different specimens during softening and melting depending on the viscosity, surface tension and wetting behaviour of the slag formed during melting. The specimens sometimes swell and sometimes shrink in addition to softening. Some specimens kept their shape during early melting, while others very quickly became bellshaped

To find out if the method produced results comparable to other data some samples were also tested by DTA- differential thermal analysis. In general, the two methods give approximately the same results, except in the case of high viscosity samples that flow out at a temperature considerably higher than the melting temperature. The melting temperature of BOF slag measured in an air atmosphere is $1310-1330^{\circ} \mathrm{C}$ when measured with DTA; measured in the high temperature microscope, the temperatures are $1310^{\circ} \mathrm{C}$, $1340^{\circ} \mathrm{C}$ and $1350^{\circ} \mathrm{C}$ for softening, melting and flow point, respectively. The melting points of three samples, corresponding to a high injection level of BOF slag, burnt lime and burnt dolomite, respectively, are also measured by DTA in an air atmosphere. The melting temperatures measured with DTA are in the same temperature interval as those measured in the high temperature microscope, except for the sample containing BOF slag. The lower melting temperature measured by DTA as compared to that measured by the high-temperature microscope might be explained by the fact that an air atmosphere was used in the DTA, while an $\mathrm{N}_{2}$ atmosphere was used in the high temperature microscope. The sample with BOF slag contains both $\mathrm{Fe}_{\text {met }}$ and $\mathrm{Fe}^{2+}$ that can be oxidised in the air atmosphere. The reproducibility of measurement in the high temperature microscope is good with homogeneous samples of low viscosity; the difference between repeated samples is less than $10^{\circ} \mathrm{C}$.

\section{Theoretical Estimations}

Melting temperatures are estimated by calculations done by the computer program Chemsage ${ }^{13)}$ using a thermodynamic data file ${ }^{14-19)}$ for multi-component slags. The model used has no data for $\mathrm{P}_{2} \mathrm{O}_{5}$ or $\mathrm{V}_{2} \mathrm{O}_{5}$. The $\mathrm{N}_{2}$ atmosphere is assumed to be as in the laboratory measurements. Estimations are made both with and without a metallic iron phase present and the calculation results are found to be the same for both conditions. Estimations are made for the chemical compositions of tuyere slag stated in Table 3.
Table 4. Temperatures for softening, active melting and flow out of measured in the high temperature microscope.

\begin{tabular}{|l|c|c|c|c|}
\hline Sample & Softening & $\begin{array}{c}\text { Active } \\
\text { melting }\end{array}$ & $\begin{array}{c}\text { Flow } \\
\text { point }\end{array}$ & $\begin{array}{c}\text { Melting } \\
\text { interval }\end{array}$ \\
\hline Coke ash & 1567 & 1593 & 1608 & 41 \\
\hline Coal ash & 1331 & 1350 & 1430 & 99 \\
\hline BOF slag & 1305 & 1347 & 1364 & 59 \\
\hline No inj. of fluxes & 1435 & 1477 & 1570 & 135 \\
\hline Low BOF slag & 1215 & 1245 & 1290 & 75 \\
\hline Medium BOF slag & 1200 & 1223 & 1245 & 45 \\
\hline High BOF slag & 1207 & 1217 & 1225 & 18 \\
\hline Very high BOF slag & 1196 & 1203 & 1241 & 45 \\
\hline Low lime & 1206 & 1298 & 1408 & 202 \\
\hline Medium lime & 1193 & 1203 & 1337 & 144 \\
\hline High lime & 1163 & 1198 & 1219 & 56 \\
\hline Very high lime & 1185 & 1213 & 1250 & 65 \\
\hline Low dolomite & 1200 & 1215 & 1253 & 53 \\
\hline Medium dolomite & 1185 & 1200 & 1290 & 105 \\
\hline High dolomite & 1163 & 1229 & 1330 & 167 \\
\hline Very high dolomite & 1210 & 1297 & 1395 & 185 \\
\hline
\end{tabular}

\section{Results}

\subsection{Melting-point Measurements}

The results of melting-point measurements are summarised in Table 4. The coke ash has the highest softening and melting range-from 1567 to $1608^{\circ} \mathrm{C}$, while that of the coal ash is much lower-from 1300 to $1430^{\circ} \mathrm{C}$, and the BOF slag from 1305 to $1364^{\circ} \mathrm{C}$. A sample consisting of a mixture of coke ash and coal ash has higher softening and melting points than a sample of coal ash, while the softening and melting points are lower than those of coke ash on its own.

The results also show that the presence of BOF slag, burnt lime or dolomite in the specimens lowers the melting temperature significantly. The BOF slag also decreases the softening and melting temperature interval for all injection levels, while the lime gives some decrease only in the two cases, with high and very high injection rate, and the dolomite gives a decrease only in the case with a low injection level. The result is shown in Table 4 and Fig. 4. For the specimens corresponding to low and medium injection levels of burnt lime and high and very high injection levels of dolomite, the samples started softening at rather low temperatures and the temperature intervals between softening and flow out were much wider than for other samples. On the contrary, the specimens containing BOF slag, especially the one corresponding to the high injection rate, melted very quickly and actively. Some of the specimen material even ripped off during melting, indicating a very low melt viscosity. The samples containing BOF slag normally formed a flat bell during melting, while the samples containing lime formed a hemisphere. All samples start to melt at the top of specimens and the slag melt formed is wetting the alumina substrate for all specimens tested. The differences in the melting properties of the specimens with BOF 
slag, lime and dolomite can also be clearly seen in Fig. 4. The introduction of BOF slag has a more beneficial effect on the decrease in the softening and melting temperature interval than the introduction of burnt lime and dolomite

As shown in Table 3, the amounts of BOF slag and burnt lime have been chosen equitably to generate tuyere slags with the same basicity $\mathrm{B} 2 \quad\left(\mathrm{~B} 2=\mathrm{wt} \% \mathrm{CaO} / \mathrm{wt} \% \mathrm{SiO}_{2}\right)$. However, if the $\mathrm{MgO}$ and $\mathrm{Al}_{2} \mathrm{O}_{3}$ contents in the slags are included and considered as $\mathrm{CaO}$ and $\mathrm{SiO}_{2}$ on a molar basis, the values of basicity $\mathrm{B} 4(\mathrm{~B} 4=[(\mathrm{wt} \% \mathrm{CaO}+1.4 \mathrm{wt} \% \mathrm{MgO}) /$ $\left.\left(\mathrm{wt} \% \mathrm{SiO}_{2}+0.59 \mathrm{wt} \% \mathrm{Al}_{2} \mathrm{O}_{3}\right)\right]$ for the slags formed will be quite different for the specimens containing BOF slag, burnt lime and dolomite, respectively. Due to a high $\mathrm{MgO}$ content, especially the specimens containing dolomite, but also the ones containing BOF slag, will have much higher basicity B4 than the specimens containing lime. For instance, three samples with almost the same basicity B2, 1.17 for the BOF-doped specimen, 1.16 and lime-doped specimen and 1.18 for the dolomite-doped specimen, differ considerably with respect to basicity B4; 1.35 for the BOFdoped specimen, 0.93 for the lime-doped specimen and 1.75 for the dolomite-doped one. This means that injection of BOF slag, lime and dolomite will give different basicity B4 in tuyere slag, although basicity B2 is the same.
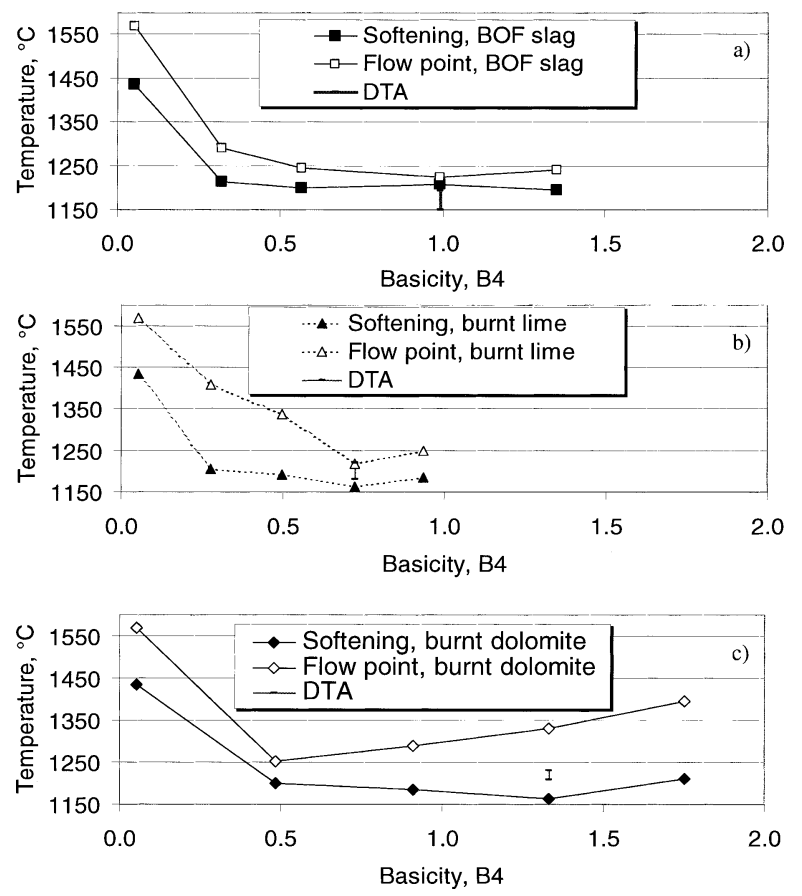

Fig. 4. Measured softening and flow out temperatures of the specimens based on no injection and injection of BOF slag (a), burnt lime (b) and burnt dolomite (c). The basicity $\mathrm{B} 4$ on the $x$-axis corresponds to the different injection levels.
Injection of BOF slag will give the tuyere slag an intermediate basicity B4, compared to lime and dolomite, but still with a rather low melting point and a narrow temperature interval. This implies that the injection of BOF slag, as compared to injection of lime, might also be more beneficial for desulphurisation in front of the tuyeres. If the softening and melting temperatures are compared based on approximately the same basicity B4, the addition of BOF slag gives the same or lower flow point as compared to addition of lime or dolomite. The softening and melting temperature interval of the specimens containing BOF slag is also narrower.

\subsection{Theoretical Estimations}

As can be seen in Table 5 the estimations show that the BOF slag decreases the melting temperature for all injection levels assumed, while burnt lime and burnt dolomite increase the temperature of start of melting. The temperatures corresponding to $85 \%$ melt formed from the mixture decrease for all additions of fluxes. The temperature interval for melting is narrower when fluxes are added to the mixture of coal and coke ash. The proportion of melts formed at $1650^{\circ} \mathrm{C}$ increases when fluxes are added. Examples of this can be seen from the melting curves in Figs. 5, 6 and 7 shows the chemical composition of the slag melt formed. The first melt formed is in general a low-basicity slag melt, which contains the main part of the manganese and iron oxides. When an increased temperature is assumed, mainly $\mathrm{CaO}$, but also $\mathrm{MgO}$ and $\mathrm{Al}_{2} \mathrm{O}_{3}$, are dissolved into the slag melt. The final basicity achieved in the tuyere slag depends on the assumed injection level of fluxes.

\section{Discussion}

\subsection{Differences between the Specimens Containing BOF Slag, Lime and Dolomite}

According to the laboratory results obtained, the improvement of slag formation in front of the tuyeres can be expected if injection of fluxes into the blast furnace is used. Although BOF slag, lime and dolomite can decrease the melting point of the tuyere slag significantly, it seems that the injection of BOF slag improves the properties of the tuyere slag more than does the injection of lime or dolomite, in terms of lower melting point and narrower temperature interval between softening and flow out and possibly also a lower viscosity, at all injection levels studied.

This may be explained by the following reasons.

(a) The BOF slag contains a larger amount of components such as $\mathrm{FeO}, \mathrm{MnO}, \mathrm{TiO}_{2}$ and $\mathrm{V}_{2} \mathrm{O}_{5}$ that are included

Table 5. Estimated temperatures for first melt formed and the ratio of melt at $1650^{\circ} \mathrm{C}$.

\begin{tabular}{|l|c|c|c|c|c|c|c|c|c|}
\hline & \multicolumn{3}{|c|}{ BOF slag } & \multicolumn{3}{c|}{ Burnt lime } & \multicolumn{3}{c|}{ Burnt dolomite } \\
\cline { 2 - 12 } & $\begin{array}{c}\text { First melt, } \\
\text { temperature } \\
{ }^{\circ} \mathrm{C}\end{array}$ & $\begin{array}{c}>85 \% \text { melt } \\
\text { temperature } \\
{ }^{\circ} \mathrm{C}\end{array}$ & $\begin{array}{c}\text { Ratio of } \\
\text { melt at } \\
1650^{\circ} \mathrm{C}\end{array}$ & $\begin{array}{c}\text { First melt, } \\
\text { temperature } \\
{ }^{\circ} \mathrm{C}\end{array}$ & $\begin{array}{c}>85 \% \text { melt } \\
\text { temperature } \\
{ }^{\circ} \mathrm{C}\end{array}$ & $\begin{array}{c}\text { Ratio of } \\
\text { melt at } \\
1650^{\circ} \mathrm{C}\end{array}$ & $\begin{array}{c}\text { First melt, } \\
\text { temperature } \\
{ }^{\circ} \mathrm{C}\end{array}$ & $\begin{array}{c}>85 \% \text { melt } \\
\text { temperature, } \\
{ }^{\circ} \mathrm{C}\end{array}$ & $\begin{array}{c}\text { Ratio of } \\
\text { melt at } \\
1650^{\circ} \mathrm{C}\end{array}$ \\
\hline None & 1100 & 1500 & $86 \%$ & 1100 & 1500 & $86 \%$ & 1100 & 1500 & $86 \%$ \\
\hline Low & 1050 & 1250 & $91 \%$ & 1100 & 1400 & $89 \%$ & 1100 & 1350 & $92 \%$ \\
\hline Medium & 1000 & 1300 & $97 \%$ & 1250 & 1350 & $94 \%$ & 1100 & 1350 & $99 \%$ \\
\hline High & 1000 & 1250 & $100 \%$ & 1250 & 1400 & $99 \%$ & 1150 & 1400 & $98 \%$ \\
\hline Very high & 1000 & 1350 & $98 \%$ & 1250 & 1400 & $99 \%$ & 1150 & 1450 & $99 \%$ \\
\hline
\end{tabular}




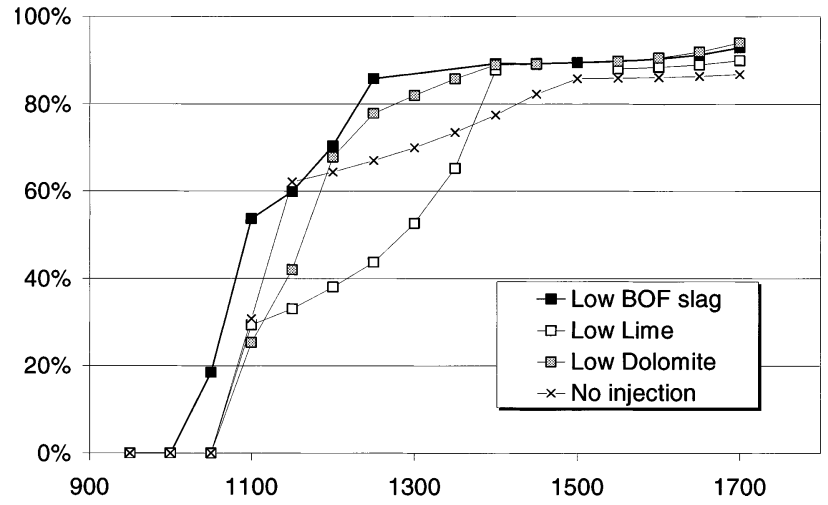

Fig. 5. Ratio of slag melt and main chemical composition of the slag melt formed at the high injection level. From top to bottom injection of BOF slag (a), burnt lime (b) and burnt dolomite (c) respectively.

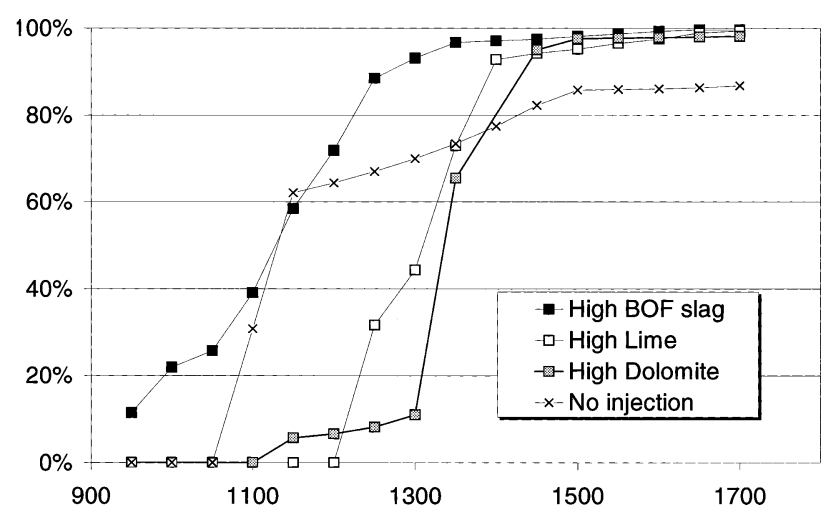

Fig. 6. Estimated ratio (\%) of melt formed, at different temperatures, in tuyere slag specimens corresponding to no injection of fluxes and low injection level of fluxes.

in neither the basicity formulas nor in the phase diagrams. These components could further decrease the melting point or/and the viscosity of the slag formed. Estimations in Chemsage show that the first slag melt formed is a low basicity slag containing the main part of the iron and manganese oxides.

(b) The BOF slag injected is a slag already formed in the converter and having a comparatively low melting point, while the burnt lime used has a high content of $\mathrm{CaO}$ and the dolomite used has a high content of $\mathrm{CaO}$ and $\mathrm{MgO}$, both of which have a much higher melting point. Therefore, the former will be re-melted and dissolved into other components much easier than the latter two, which probably require more time and an even higher temperature for dissolution.

(c) The concentration of alumina in the tuyere slag will be lower in the case of BOF slag injection than in the case of lime injection, because a larger amount of BOF slag is needed compared to that of lime to give the same basicity B2 in the tuyere slag. The concentration of alumina will also be lower with BOF slag injection as compared to dolomite injection, although the difference is smaller.

\subsection{Comparison of Measured Melting Temperatures and Melting Temperatures Estimated with Chemsage}

The results from melting-point measurements and from
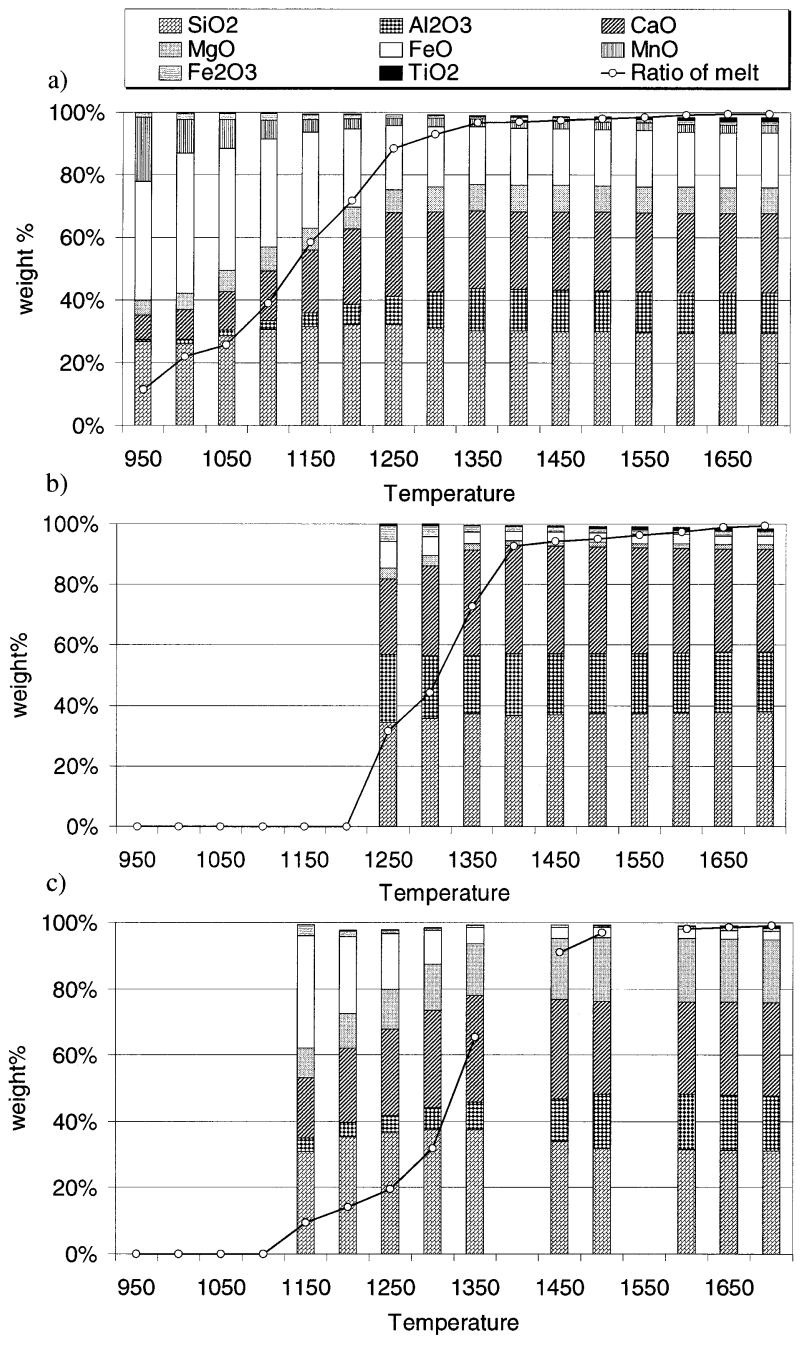

Fig. 7. Estimated ratio (\%) of melt formed, at different temperatures, in tuyere slag specimens corresponding to no injection of fluxes and high injection level of fluxes.

estimations of melting points with Chemsage are compared in Fig. 8. The flow-out temperature is compared with the estimated temperature for $>85 \%$ of melt formed in the computer calculations. When comparing these results it is important to realise that the relationship between the amount of melt formed and flow out is effected by the viscosity of melt just above the melting temperature. The correlation is quite good for BOF slag. For burnt dolomite the tendency of the curves for measured and estimated values is the same, but the estimated temperatures are higher, except for the case without injection of fluxes. The correlation for the cases with low and medium injection level of burnt lime is good, but the difference is quite large in the case of high and very high injection levels. The reason might be a partial dissolution of burnt lime into the slag melt. It could be expected that the BOF slag dissolves into the slag melt better than burnt lime and burnt dolomite, as a result of the lower melting temperature of the former. There is a risk that the burnt lime and burnt dolomite are not totally dissolved into the slag melt and therefore the melting temperature interval will correspond to a lower injection level than assumed. 


\subsection{Quaternary Systems of $\mathrm{Al}_{2} \mathrm{O}_{3}-\mathrm{CaO}-\mathrm{MgO}-\mathrm{SiO}_{2}$ and of $\mathrm{Al}_{2} \mathrm{O}_{3}-\mathrm{CaO}-\mathrm{FeO}_{x}-\mathrm{SiO}_{2}$}

The chemical compositions of the specimens according to Table 3 are transferred into four main oxides; $\mathrm{CaO}, \mathrm{MgO}$, $\mathrm{SiO}_{2}$ and $\mathrm{Al}_{2} \mathrm{O}_{3}$ and $\mathrm{CaO}, \mathrm{FeO}, \mathrm{SiO}_{2}$ and $\mathrm{Al}_{2} \mathrm{O}_{3}$, respectively. Estimations of melting temperatures according to the phase diagrams $\mathrm{s}^{20)}$ and by calculations in Chemsage are listed in Table 6.

\subsubsection{Estimations Based on Phase Diagrams}

The values estimated from phase diagrams ${ }^{20}$ ) of the $\mathrm{Al}_{2} \mathrm{O}_{3}-\mathrm{CaO}-\mathrm{MgO}-\mathrm{SiO}_{2}$ and $\mathrm{Al}_{2} \mathrm{O}_{3}-\mathrm{CaO}-\mathrm{FeO}_{x}-\mathrm{SiO}_{2}$ systems are generally higher than the measured results, except for the estimations made with the latter system for two specimens corresponding to a high injection level of BOF slag or burnt dolomite. Estimations based on the quaternary system $\mathrm{Al}_{2} \mathrm{O}_{3}-\mathrm{CaO}-\mathrm{FeO}_{x}-\mathrm{SiO}_{2}$ differ less from the measured values compared to estimations based on the $\mathrm{Al}_{2} \mathrm{O}_{3}-\mathrm{CaO}-\mathrm{MgO}-\mathrm{SiO}_{2}$ system. The considerable influence

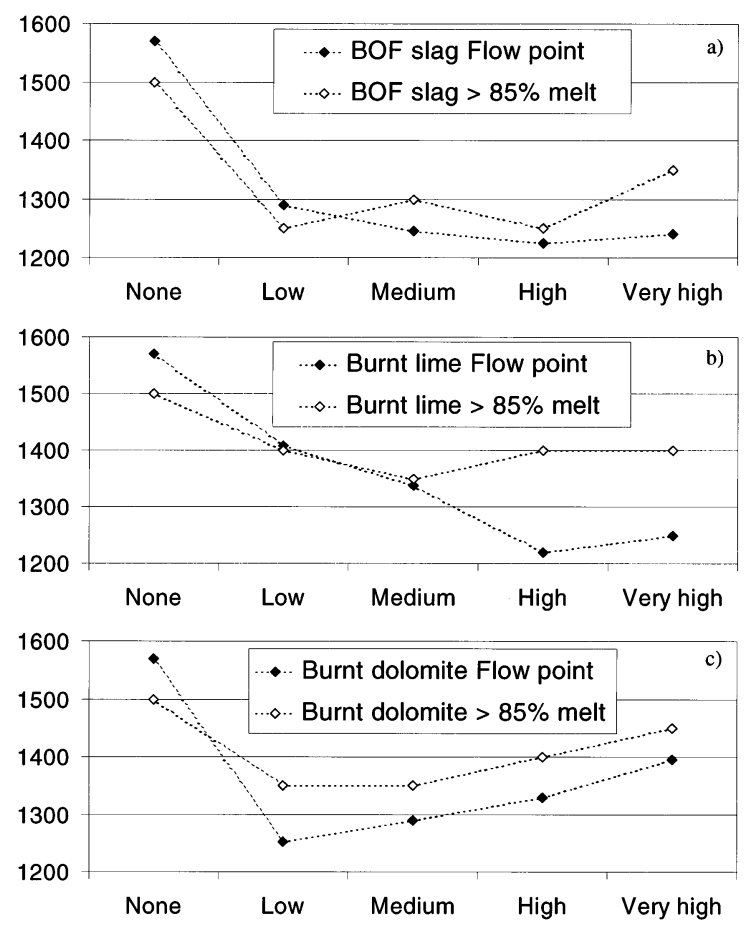

Fig. 8. Comparison of measred and estimated flow points. of $\mathrm{FeO}$ on the melting point may explain the better correlation between the estimated and measured results when using the quaternary system $\mathrm{Al}_{2} \mathrm{O}_{3}-\mathrm{CaO}-\mathrm{FeO}_{x}-\mathrm{SiO}_{2}$.

\subsubsection{Estimations Made by Chemsage}

The same data - normalised chemical composition based on four oxides - as used in the estimation of melting points by phase diagrams are used in estimations with the computer program Chemsage. The results can be seen in Table 6 . In general, the data estimated by the phase diagrams are found in the melting interval calculated in Chemsage. One exception is the estimation for the chemical composition corresponding to no injection of fluxes. The calculations indicate that $\mathrm{MgO}$ and $\mathrm{CaO}$ increase the temperature for start of melting, but decrease the temperature of final melt out. If $\mathrm{FeO}$ is present, an increase in $\mathrm{CaO}$ content will decrease the start of melting temperature at low basicities and decrease the temperature for final melt out. If both the $\mathrm{FeO}$ content and the $\mathrm{CaO}$ content increase, the start of melting temperature will decrease at the same time as the temperature for final melt out is kept at a low and constant level.

\section{Conclusions}

A study has been carried out concerning the effect of tuyere-injected fluxes on the melting properties of tuyere slag using theoretical calculations and laboratory experiments. The results indicate that injection of fluxes improves the melting properties of tuyere slag in terms of increased basicity, decreased softening and melting temperatures and decreased softening and melting temperature interval. This will improve the drainage of slag from the raceway area of the BF. The results also show that, as compared to lime or dolomite, injection of BOF slag generally has approximately the same or a better effect on the tuyere slag properties mentioned for all injection levels tested.

\section{Acknowledgements}

I am grateful to the Swedish Steel Producers' Association (Jernkontoret) for financial support and also wish to thank the members of the committee, Injection into the Blast Furnace. I thank my company, SSAB Tunnplåt in Luleå, for giving me the opportunity to do this study. I appreciate the assistance given by Johan Eriksson, Birgitta

Table 6. Comparison between the measured flow points obtained in this study and estimated values from phase diagrams (*) and estimations by calculations in Chemsage $(* *)$ of the quaternary systems of $\mathrm{Al}_{2} \mathrm{O}_{3}-\mathrm{CaO}-\mathrm{MgO}-\mathrm{SiO}_{2}$ and $\mathrm{Al}_{2} \mathrm{O}_{3}-\mathrm{CaO}_{-}-\mathrm{FeO}_{x}-\mathrm{SiO}_{2}$.

\begin{tabular}{|c|c|c|c|c|c|}
\hline \multirow[b]{2}{*}{ Tuyere slag mixture } & \multicolumn{2}{|c|}{$\begin{array}{c}\text { Based on } \mathrm{Al}_{2} \mathrm{O}_{3} \mathrm{CaO}-\mathrm{MgO} \\
\mathrm{SiO}_{2-}\end{array}$} & \multicolumn{2}{|c|}{$\begin{array}{c}\text { Based on } \mathrm{Al}_{2} \mathrm{O}_{3} \mathrm{CaO}-\mathrm{FeO} \mathrm{O}_{x} \\
\mathrm{SiO}_{2}\end{array}$} & \multirow{2}{*}{$\begin{array}{c}\text { Measured } \\
\text { flow point, } \\
{ }^{\circ} \mathrm{C}\end{array}$} \\
\hline & $\begin{array}{c}\text { Estimated }^{*} \\
\text { melting } \\
\text { point, }{ }^{\circ} \mathrm{C}\end{array}$ & $\begin{array}{c}\text { Estimated }^{* * *} \\
\text { melting } \\
\text { interval, }{ }^{\circ} \mathrm{C}\end{array}$ & $\begin{array}{c}\text { Estimated }^{*} \\
\text { melting } \\
\text { point, }{ }^{\circ} \mathrm{C}\end{array}$ & $\begin{array}{c}\text { Estimated }^{* * *} \\
\text { melting } \\
\text { interval, }{ }^{\circ} \mathrm{C}\end{array}$ & \\
\hline No injection of fluxes & 1640 & $1200-1500$ & 1680 & $1200-1500$ & 1570 \\
\hline Low injection of BOF slag & 1400 & $1200-1400$ & 1390 & $1150-1350$ & 1290 \\
\hline Medium injection of BOF slag & 1350 & $1250-1350$ & 1320 & $1150-1350$ & 1245 \\
\hline High injection of BOF slag & 1360 & $1300-1400$ & 1210 & $1100-1350$ & 1225 \\
\hline Very high injection of BOF slag & 1460 & $1300-1400$ & 1330 & $1050-1350$ & 1241 \\
\hline Low injection of burnt lime & 1500 & $1250-1450$ & 1450 & $1150-1450$ & 1408 \\
\hline Medium injection of burnt lime & 1390 & $1250-1450$ & 1370 & $1150-1400$ & 1337 \\
\hline High injection of burnt lime & 1350 & $1350-1400$ & 1300 & $1300-1400$ & 1219 \\
\hline Very high injection of burnt lime & 1440 & $1350-1450$ & 1350 & $1300-1450$ & 1250 \\
\hline Low injection of burnt dolomite & 1400 & $1200-1350$ & 1450 & $1150-1450$ & 1253 \\
\hline Medium injection of burnt dolomite & 1390 & $1300-1450$ & 1380 & $1150-1400$ & 1290 \\
\hline High injection of burnt dolomite & 1495 & $1400-1550$ & 1300 & $1300-1400$ & 1330 \\
\hline Very high injection of burnt dolomit & 1680 & $1450-1550$ & 1450 & $1300-1450$ & 1395 \\
\hline
\end{tabular}


Nyberg and Chak Kei To with equipment preparation and laboratory work, and I am grateful to Bo Lindblom for his assistance in calculation. I also extend my thanks to Bo Björkman, Jan-Olov Wikström and Guanqing Zuo for fruitful technical discussions. A special thanks to Professor Jitang Ma, whose idea this work is based on.

\section{REFERENCES}

1) J. Ma: ISIJ Int., 39 (1999), 697.

2) L. S. Ökvist, G. Zuo and J. Ma: Sixth Int. Conf. on Molten Slags, Fluxes and Salts, KTH, Stockholm, (2000).

3) L. S. Ökvist and G. Zuo: 7th Nordic-Japanese Symp., ISIJ, Tokyo, (2000).

4) S. Komatsu, K. Sato, C.Yamagata, Y. Kajiwara and S. Suyama: Proc. of the 6th Int. Iron and Steel Cong., ISIJ, Tokyo, (1990), 558.

5) K. Takeda, Y. Sawa, S. Taguchi, N. Takashima, T. Matsumoto, H. Obata: Proc. of the 6th Int. Iron and Steel Cong., ISIJ, Tokyo, (1990), 566.

6) K. Kushima, M. Naito, K. Shibata, H. Sato, H. Yoshida and M. Ichida: Ironmaking Conf. Proc., ISS, Warrendale, PA, (1988), 457.

7) G. Brun, R. Nicolle, J. M. Steiler, J. L. Bouttement, J. L. Eymond and J. P. Menaut: La Reveue de Métallurgie, 85 (1988), 21.

8) C. Yamagata, Y. Kajiwara, S. Suyama and T. Miyake: ISIJ Int., 30 (1990), No. 9, 740.
9) T. Sugiyama, T. Nakagawa, H. Shibaike and Y. Oda: Tetsu-toHagané, 73 (1987), 2044.

10) T. Fukutake and K. Okabe: Trans. Iron Steel Inst. Jpn., 16 (1976), 317.

11) A. Dahlstedt, M. Hallin and M. Tottie: 1st Int. Conf. on Process Development in Iron and Steelmaking, MEFOS, Luleå Sweden, (1999), 235.

12) Ruhrkohlen Handbuch, 7th Ed., Ruhrkohle-Verkauf GmbH, Verlag Glückauf, Essen, (1987).

13) G. Eriksson and K. Hack: Metall. Trans. B, 21B (1990), 1012.

14) H. Gaye and D. Coulombet: Donnees thermochimiques et cinetiques relatives a certains materiaux siderurguques, PCM84-RE 1064, IRSID, (1984)

15) A. Hauck and O. Knacke: Steel Res., 56 (1985), No 10, 501.

16) H. Gaye and J. Welfringer: Modelisation des proprietes thermodynamiques des laitiers phosphates, PCM 87-N 124, IRSID, (1987).

17) PJ. Spencer and K. Hack: Swiss Plastics, 13 (1991), No. 9, 63, 66, 68.

18) H. Gaye and J. Welfringer: Modelling of the Thermodynamic Properties of Complex Metallurgical Slags, 2nd Int. Symp. on Metallurgical Slags and Fluxes, Metallurgical Society of AIME, Warrendale, PA, (1984).

19) E. Koenigsberger: Private communication.

20) Slag Atlas 2nd Ed., Verein Deutscher Eisenhüttenleute (VDEh), Verlag Stahleisen GmbH, Düsseldorf, (1995), 154, 156, 381. 